Animal Health Research Institute

Assiut Regional Laboratory

\title{
MICROBIOLOGICAL EVALUATION OF SOME \\ DAIRY DESSERTS SOLD BY DAIRY SHOPS \\ AND SERVED AT SOME RESTAURANTS \\ IN ASSIUT CITY \\ (With 9 Tables)
}

By

AMAL ALI ABDEL-HALEEM;

M.K. MOUSTAFA * and AHMED A-H. AHMED *

* Dept. of Food Hygienc, Fac. Vet. Med. Assiut University

(Received at 20/2/2001)

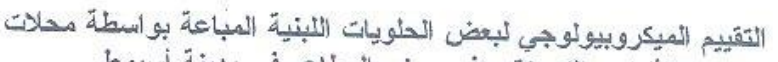

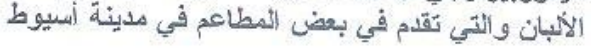

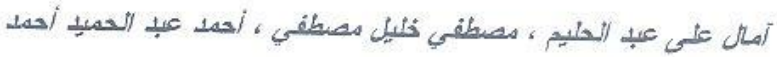

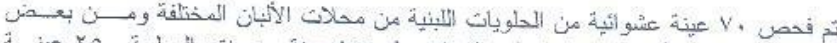

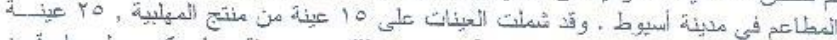

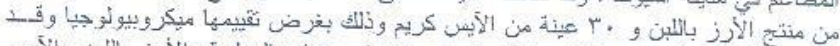

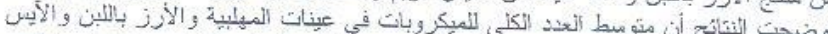

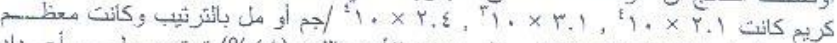

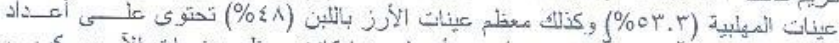

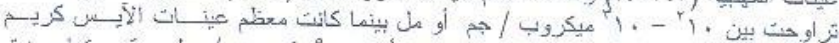

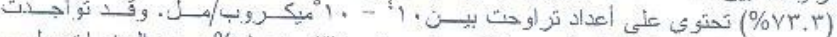

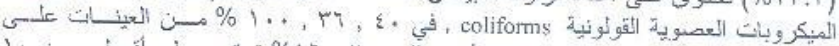

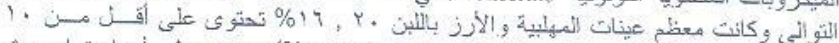

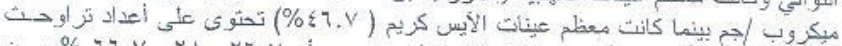

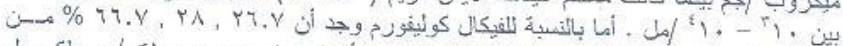

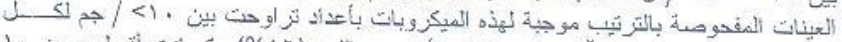

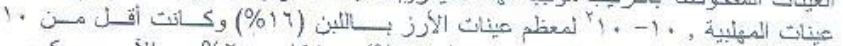

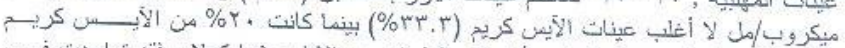

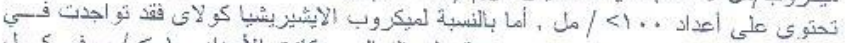
.

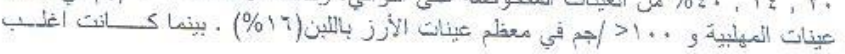




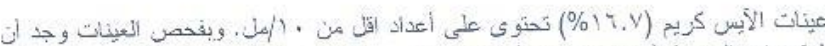

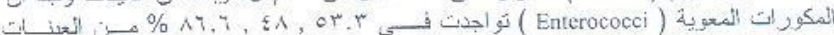

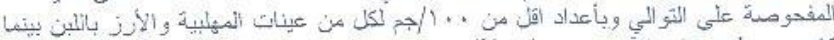

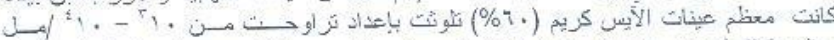

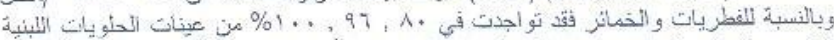

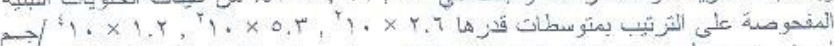

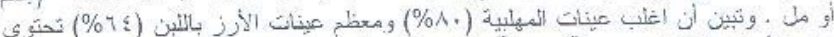

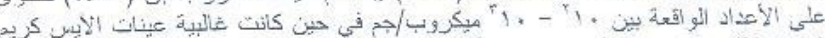

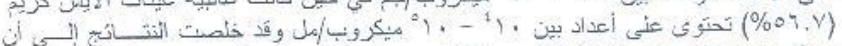

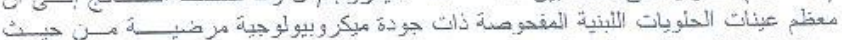

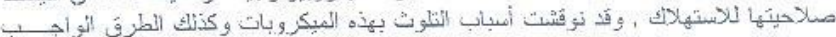

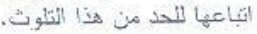

\section{SUMMARY}

Seventy random samples of dairy desserts were colected from different dairy shops and some restaurants in $\Lambda$ ssiut City. The samples included mehallabeia ( 15 samples), rice with milk ( 25 samples) and ice cream ( 30 samples). The obtained results showed that the average counts of Aerobic plate count were $2.1 \times 10^{4}, 3.1 \times 10^{3}$ and $2.4 \times 10^{4} / \mathrm{g}$ or ml of the examined samples, respectively. It was found that most of mehallebeia samples $(53.3 \%)$ and rice with milk samples $(48 \%)$ contained numbers ranged from $10^{2}-10^{3} / \mathrm{g}$, while the majority of ice cream samples $(73.3 \%)$ lies within the range of $10^{4}-10^{5} / \mathrm{ml}$. Coliforms existed in 40,36 and $100 \%$ of the examined desserts respectively. Most of the examined samples of mchallabeia $(20 \%)$ had counts $<10 / \mathrm{g}$. Also, most of rice with milk samples $(16 \%)$ had the same counts of coliforms $/ g$. The majority of icc cream samples $(46.7 \%)$ had counts ranged from $10^{3}-10^{4}$ coliforms/ml. liecal coliforms existed in $26.7,28$ and $66.7 \%$ of the examined samples, respectively, in numbers of less than $10 / \mathrm{g}$ for all positive samples of mehallabeia and $10-10^{2}$ for most of positive samples $(16 \%)$ of rice with milk. The majority of ice cream samples $(33.3 \%)$ had counts $<10$ fecal coliforms $/ \mathrm{ml}$. Concerning $E$. coli, the organism was detected in 20,24 and $40 \%$ of the examined samples, respectively in numbers below 10 organisms $/ \mathrm{g}$ for all positive samples of mehallabeia and $10-10^{2} / \mathrm{g}$ in $16 \%$ of rice with milk, while most of ice cream samples $(16.7 \%)$ had counts of less than $10 \mathrm{E}$. coli $/ \mathrm{ml}$. The entrococci contaminated $53.3,48$ and $86,6 \%$ of the examined dairy desserts samples, respectively in average counts of $4100 / \mathrm{g}$ of mehallabeia and 
rice with milk, and $8.1 \times 10^{3} / \mathrm{ml}$ as an average count for ice cream. Most of ice cream samples $(60 \%)$ had numbers of enterococci within the range of $10^{3}-10^{4}$ organisms $/ \mathrm{ml}$. Total yeast and molds were detected in 80,96 and 100 of the examined samples, respectively. The average counts were respectivcly $2.6 \times 10^{2}, 5.3 \times 10^{2}$ and $1.2 \times 10^{4} / \mathrm{g}$ or $\mathrm{ml}$. All of the positive samples of mehallabeia $(80 \%)$ and rice with milk $(64 \%)$ had counts ranged from $10^{2}-10^{3}$, while most of ice cream samples $(56.7 \%)$ contained the organisms in numbers between $10^{4}-10^{5} / \mathrm{ml}$. The public heal th hazards and preventive measures were discussed.

Key words: Microbiology, dairy, desserts.

\section{INTRODUCTION}

Dairy desserts are popular dairy foods usually prepared and served after meals at homes or restaurants or may be served alone. These desserts are prepared from ingredients that milk is the base constituent. Of these desserts meballabeia, rice with milk, custard and ice cream are almostly the popular dairy desserts in Egypt and are usually consumed cooled or frozen (ice cream) by a wide range of people of all ages. The products mehallabeia and rice with milk are prepared by adding corn starch (in a little of cooled milk or water) or rice to the sweetened milk (by sugar) during boiling with continous mixing till complete cooking and taking the desired consistency. Falvoring material, (mainly vanilla) and nuts are added to the product after preparation. These products are distributed in containers and served cooled, so they are kept in
refrigerator till use.

No provability is needed to state that dairy desserts are platable, nutritive, healthful and relatively inexpensive dairy food. Concerning the desserts mehallabeia and rice with milk, the data dealt with their microbial quality are sketchy or totally absent. However, ice cream as a worldwide popular product has reccived extensive research works that explored its microbial quality, so far (Abo-Zeid, 1990; Spolaor et al.. 1990; Ahmed and Sallam, 1991; E1-Bagoury, 1992; Mahmoud, 1993 and Abdel-Haleem, 1995).

Because icc cream is consumed sometimes without any preparation that might reduce its microbial load (small scale producers and street vendors types), it is necessary to maintain a high level of microbial quality. For this purpose, many countries have adopted 
mandatory manufacturing practices and standards to ensure an adequate and wholesome supply of such product. However, numcrous epidemics and food poisoning outbreaks have been traced to consumption of contaminated ice cream (Anuszs, 1980; Bryan, 1981; Galbraith et al. 1982 and Kramer and Gilbert, 1989).

This work was performed to secure the quality of some popular dairy desserts which are served after meals at some restaurants or sold by dairy shops.

\section{MATERIAL and METHODS}

Collection of samples:

Seventy (70) random samples of dairy desserts comprising, mehallabeia (15 samples) rice with milk ( 25 samples) and ice cream (30 samples), were collected from different restaurants and dairy shops in Assiut City. Each sample was obtained in its container as it is served or sold to the public. The samples were dispatched directly to the laboratory with a minimum of delay, where they wore prepared and examined.

Preparation of samples:

Mehallabcia and rice with milk samples were mixed thoroughly, and then 10 gram were weighed in sterile stainless steel cups. Ice cream samples were left to melt in a thermostatically controlled water bath at $44^{\circ} \mathrm{C}$ for not more than $15 \mathrm{~min}$ (A.P.H.A, 1978).

Preparation of serial dilution:

10 grams of prepared mehallabeia or rice with milk were mixed with $90 \mathrm{ml}$ of sterile one tenth percent peptone water and thoroughly mixed to give a dilution $1 / 10$. Also $10 \mathrm{ml}$ of well mixed and melted icc crcam samples were transferred into flask containing $90 \mathrm{ml}$ of sterile one tenth percent peptone water to obtain a dilution 1/10. Decimal dilutions were prepared using a sterile buffering pepton water as recommended by A.P.H.A (1978).

Microbiological examination:

Fach sample was cxamined for:

1 - Aerobic plate count as described by A.P.H.A. (1978).

2- Presumptive test for coliforms group (MPN/g or ml) and the confirmed test for coliforms group as recommended by A.O.A.C. (1975).

3- Confirmed test for fecal coliforms (M.P.N/g or ml) as described by A.O.A.C.(1975)

4- Test for E. coli as recommended by A.O.A.C. (1975) 
5- Enterococci count as described by Deibel and Hartman (1976).

6- Total yeast and mold count as described by Harrigan and Margaret (1976).

\section{RESULTS}

All the results obtained are recorded in Tables from 1-9

\section{DISCUSSYON}

Looking into the results of acrobic plate count presented in Tables 1 and 2 , reveales that the total numbers of bacteria in the examined samples of mehallabeia varied from $10^{2}-2.8 \times 10^{5}$ with an average of $2.1 \times 10^{4} / \mathrm{g}$. Most of the examined samples (53.3\%) had counts between $10^{2}-10^{3} / \mathrm{g}$, while $40 \%$ of the samples had numbers varied from $10^{3}-10^{4} / g$. The examined samples of rice with milk were contaminated by bacteria in numbers ranged from $10^{2}$ as a minimum and $1.9 \times 10^{4}$ as a maximum with an average count of $3.1 \times 10^{3} / \mathrm{g}$. The highest frequency distribution ( $48 \%$ ) lies within the range of $10^{3}-10^{4}$, while $40 \%$ of samples were contaminated by bacteria varied from $10^{2}-10^{3} / \mathrm{g}$. Examination of ice cream samples for total counts (Tables 1 \& 2) veriflys that $4.3 \times 10^{2}$ and $8 \times 10^{4}$ were the minimum and maximum counts of bacteria $/ \mathrm{ml}$, respectively with $2.4 \times 10^{4} / \mathrm{ml}$ as an average count. Most of the examined ice cream samples $(73.3 \%)$ had counts within the range of $10^{4}-10^{5} / \mathrm{ml}$. Higher counts were obtained by Yang et al. (1991) who found that $11 \%$ of ice cream samples had counts exceeded $10^{5} / \mathrm{ml}$, while Abdel-Haleem (1995) recorded the same numbers of bacteria $\left(10^{4}-10^{5} / \mathrm{ml}\right)$ for the highest frequency distribution, however he counted higher numbers of bacteria in the rest of the ice cream samples.

Regarding the results of aerobic plate count (Table 1 \& 2) and in the absence of Eyyptian standard for total bacterial count in ice cream, it obovious that $26.7 \%$ of ice cream samples comply with the standard of International Dairy Federation (1969) and meet the requirment of Dutch Food Law (Tamminga et al., 1980). Also, they achieve the permissible limits allowed in forcign countries that total counts should not exceed $10 \% \mathrm{ml}$ (Bakki. 1976 and Luck and Lategan, 1976). 
However, most of the examined ice cream samples were on border line and had counts between $10^{4}-10^{5} / \mathrm{ml}$. From the previously discussed data (Table 1 \& 2), it is precisely evident that all of the examined samples of ice cream could be judged satisfactory as the maximum counts of our samples did not exceed $2.4 \times 10^{4} / \mathrm{ml}$. Consequently all of the examined samples of mehallabeia and rice with milk could be judged of good quality except one sample (had counts > $\left.10^{5} / \mathrm{g}\right)$.

The summarized results in Tables $3 \& 4$ pinpoint that $40 \%$ of the examined mehallabeia samples were contaminated by coliforms. The majority of the examined samples $(20 \%)$ had counts $<10$ coliforms $/ g$, while $13.3 \%$ of the samples were contaminated by the organisms in numbers ranged from $10^{3}-10^{4} / \mathrm{g}$. Also, the results showed that $36 \%$ of the examined rice with milk samples were contaminated by coliforms. Most of the samples examined $(16 \%)$ had counts below $10 / \mathrm{g}$. All of ice cream samples examined, proved to contain coliforms. The highest frequency distribution $(46.7 \%)$ lies within the range of $10^{3}-10^{4} / \mathrm{ml}$.

Concerning fecal coliforms (Table 4), low percentages of mehallabeia and rice with milk samples (26.7 and 28\%) werc contaminated by such organism in numbers less than $10 / \mathrm{g}$ of mehallabeia and less than $10^{2} / \mathrm{g}$ of rice with milk. Ice cream samples proved to have fecal coliforms in a percentage of $66.7 \%$ of the samples. Most of the examined samples (33.3\%) had fecal coliforms counts below $10 / \mathrm{g}$. Nearly similar incidence of coliforms and higher existence of fecal coliforms were recorded in ice cream examined by Abdel-Haleem (1995). Higher incidence and counts of coliforms and fecal coliforms were obtained by Abo-7eid (1990) and El-Essawy and Riad (1990), while no fecal coliforms could be detected in ice cream examined by Balacescu (1974).

Comparing the obtained results (Tables $3 \& 4$ ) with the international standards for coliforms in ice cream, it is evident that $46.7 \%$ of the examined ice cream samples did not comply with the standard of International Dairy Federation (1969) and did not meet with the requirment of WHO standard (1981) that coliforms must not exceed $10^{2} / \mathrm{ml}$. However, the rest of ice cream samples examined comply with these standards. Consequently, all of the examined samples of mehallabeia and rice with milk comply with all standards recommended for ice cream and could be judged satisfactory. 
E.coli could be isolated from 20 and $24 \%$ of the examined mehallabeia and rice with milk samples (Table 5). These samples had E.coli in numbers of less than $10^{2} / \mathrm{g}$ for rice with milk, while all of the examined mehallabeia samples had counts of less than $10 / \mathrm{g}$. Also, E coli could be detected in $40 \%$ of ice cream samples, the highest frequency distribution $(16.7 \%)$ had counts of less $10 / \mathrm{ml}$. Lower incidence and higher counts of Ecoli were recorded by Abdel-Haleem (1995), however nearly similar numbers $(<10 / g)$ of E.coli were counted in most of the positive samples. Lower findings were conducted by El-Essawy and Riad (1990), Abo-Ziad (1991); El-Bagoury (1992) and El-Leboudy et al. (1992).

It is worthwhile to state that coliform organisms including fecal coliforms and E.coli contaminating icc cream samples could be attributed to poor quality ingredients, ineffective sanitizing practices, prolonged storage of the mix and careless during handling and distribution. Furthermore, contamination of ice cream by coliforms beyond certain level should be considered a public health hazard as they may cause dreadful diarrhea disease (Robert et al., 1977). Also, occurrence of fecal coliforms in such products is a real indication of fecal pollution and possible existence of other entcric pathogens, besides the public health hazards of E.coli which have been emphasized by several investigators (Marier et al., 1973 and Mossel, 1975).

Results of enterococci (Tables $6 \& 7$ ) prove that $53.3 \%$ of the examined mehallabeia samples were contaminated by these organisms in numbers less than $100 / \mathrm{g}$. Also, enterococci were detected in $48 \%$ of the examined samples of rice with milk in counts below $100 / \mathrm{g}$. However, icc cream samples proved to be highly contaminated by such bacteria $(86.6 \%)$ in numbers varied from 10 to $6.4 \times 10^{4}$ with an average count of $8.1 \times 10^{3} / \mathrm{ml}$. Most of ice cream samples $(60 \%)$ contained the organisms in numbers ranged from $10^{3}-10^{4} / \mathrm{ml}$. Lower incidence and high counts of enterococci were found in ice cream examined by Abdel-Haleem (1995), however similar counts $\left(10^{3}-10^{4} / \mathrm{ml}\right)$ were obtained in the highest frequency distribution. Lower incidence and counts were recorded by ElBagoury (1992). No acceptable level of these bacteria can be stated, because enterococci could vary with the product, handling condition, the time of storage and other factors. The presence of these bacteria in the products mehallabcia and rice with milk $(<100 / \mathrm{g})$ could be attributed to post preparation contamination during distribution or from careless 
handling of product. Also, the heat resistance character of the organism may give another reason. The public health hazard of enterococci can not be denied as they have been implicated in several food poisoning outbreaks when exist in tremendous numbers in the product (ICMSF, 1978).

The data of Tables 8 and 9 reveal that 80,96 and $100 \%$ of the examined dairy desserts respectively were contaminated by yeast and mold in counts averaged $2.6 \times 10^{2}, 5.3 \times 10^{2}$ and $1.2 \times 10^{4} / \mathrm{g}$ or $\mathrm{ml}$. All of positive mehallabcia samples examined had counts between $10^{2}-10^{3}$ organism/g, while $64 \%$ of the rice with milk samples had numbers ranged from $10^{2}-10^{3} / \mathrm{g}$. Majority of ice cream samples subjected for total yeast and mold count $(56.7 \%)$ had numbers within the range of $10^{4}$ $10^{5} / \mathrm{ml}$. Lower incidences and counts of total yeast and mold were detected in ice cream examined by Abdcl-Haleem (1995) and Ahmed (1980). The high incidence and numbers of total yeast and mold in ice cream could be attributed to contamination of ingredients and absence of pastcurization during preparation of such product. However, their existence in the other two products is mainly due to contamination after preparation, during distribution in containers or during holding till serving.

It is oboviously evident from the aforementioned data that the two dairy desserts, mehallabcia and rice with milk were satisfactory from the quality point of view. However, special care should be taken to avoid contamination of the product after preparation. Small scale produccrs of ice cream should equipped by the facilities of pasteurization and morc efforts should be done to limit or prevent the possibility of post manufacturing contamination.

\section{REFERENCES}

A.O.A.C. (1975): Association of official analytical chemists. Official methods of analysis. 12th Ed. Po. Box 540, Benjamin liranklin Station Washington.

A.P.ILA. (1978): Standard methods for the examination of dairy products. E.H. Marth (ed) 13 th edition, American Public Health Association Inc.

Abdel-Haleem, Amal, A. .1995. Microbiological evaluation and sanitary improvement of ice cream. Ph.D. Thesis. Fac. of Vet. Med. Assiut University. 
Abo-Zaid, A.M.A. (1990): Contamination of milk and some dairy products with enteropathogenic coliform organisms. Thesis, M. V. Sc. Fac, of Vet.Med., Cairo University.

Ahmed, A.A. and Sallam, S.S. (1991): Prevalence of E. coli serotypes in raw milk and some dairy products. Assiut Vet. Med. J., 25(50): 93-97.

Ahmed, S.Il. (1980): Studies on acute gastrointestinal infections in Assiut Governorate. Ph.D.Thesis. Fac of Med. Assiut University

Anuszs, Z. (1980): Salmonellosis in man and animal in Poland in 19711978. Medycyna Veterynaryina. 36(5): 265.Dairy Sci. Abst., 43:976 (1981).

Bakki, S.J. (1976): Bacteriological aspects of ice cream manufacture. Meieriposten 65, 797-800, 80-805. Dairy Sci. Abst. 39: 182 (1977).

Balacesct, C. (1974): Comparative bacteriological studies of icc cream manufactured by different methods. Milchwissenschaft, 29.274 (Cited after Hafe\%, 1979).

Bryan, F.L. (1981): Current trends in food borne salmonellosis in the United States and Canada. J. Food Protect., 44: 394-402.

Deibel, R.H. and Hartman, P.A. (1976): The Enterococci, In compendium of Methods for the microbiological Examination of foods, M.L., speck (ed) 2nd Printing, American Public Health Assoc. Inc.

El-Bagoury, A.R.M. (1992): Incidence and Public health importance of food poisoning causative organisms in milk and some dairy products in Kaliobia Governorate. Ph.D. Thesis. Iac. of Vet. Med. Zagazig University "Benha Branch".

El-Essawy, H.A. and riad, A. A.M. (1990): Incidence of coliform organisms in cream and ice cream with special refrerence to Enteropathogenic strains of Escherichia coli. Assiut Vet. Med. J. $24,(47)$.

El-Leboudy, A. A. Kader, O and El-Cherbini, E. (1992): Prevalence of gram negative bacteria in commercially packed ice cream and pasteurized milk. Proceeding Vol.11, 5th Sc. Cong., Fac. Vet. Med. Assiut Univ. Nov. 8-10, 1992. Egypt.

Galbraith, N.S.; Forbes, P. and Clifford, C. (1982): Comunicable discases associated with milk and dairy products in England and Wales 1951-1960. Brit. Med. J. 284: 1761-1765. 
Harrigan, W.F. and Margaret, E.M. (1976); Laboratory Methods in Food: Dairy Microbiology. Academic Press London New York San Francisco.

International Commille on Microbiological Specification for Foods (ICMSF) (1978): Microorganisms in Food. 1- Their Significance of methods of enumeration 2nd Ed. Univ. of Toronto Press, Toronto. Buffalo London.

International Dairy Federation (IFD) (1969): Compostional standard for ice cream and milk ices (edibleices) produced from milk and milk products. Int. Stand., Fil. Idf. 46, 4pp.

Kramer, J.M. and Gilbert, R.J. (1989): Bacillus cereus and other bacillus species. In food borne bacterial pathogens. (edited by Doyle, M. P.). 21-70. Dairy Sci. Abst. 52, 9 (1990).

Luck, H. and Lategan, B..(1976): Hygicnic quality of ice cream. South African Journal of Dairy Technology, 8, 201 (Cited after Hafez. 1979).

Mahmoud, M.D. (1993): Prevalence of food poisoning organisms in some dairy products in Beni-Suef Governoratc. M.V.Sc. Thesis. Fac. of Vet, Med. Beni-Suef. Cairo University.

Marier, R.; Wells, J. G.; Swanson, R. C.; Callahan, W. and Mehlman, I. $J$. (1973): An outbreak of enteropathogenic $E$. coli food borno disease traced to imported French cheese, Lancet, 2,1376.

Mossel, D.A.A. (1975): microbiology of food and dairy products. Univ. of Utrecht. Fac. Vet. Med.

Robert, W.; Shannon, C.W. and Jorge, O. (I977): J. Infect. dis., 135, 485.

Spolaor, D.; Zilio, F.; Santo, ML. Dal,; Zaechello, P.; Dalsanto, ML. (1990): Methodological aspects of the microbiolgical control of ice cream. Quaderni-dell'Istituto-Lattiero-Caseariodi. Thiene No.24,61-79. Dairy Sci. Abst., 54: 5225 (1992).

World Health Organization (1981): Nutrition and food safety spain. International Digest of Health Legislation, 32, (4), 781-783. Dairy Sci. Abst. 45: 186 (1983).

Yang, Ml; XU, Sy; Liang, YM; Yuan, XS (199I): Investigation of bacterial contamination of street, Vended foods. Dairy Food and Environmental Sanitation. 11:12, 725-727. Dairy Sci. Abst., 54: 5004 (1992). 
Table 1. Statistical analytical results of aerobic plate count in the examined dairy desserts samples.

\begin{tabular}{|c|c|c|c|c|c|c|}
\hline Samples & No. of samples & \multicolumn{2}{|c|}{ Positive samples } & \multicolumn{3}{|c|}{ Count gor ml } \\
\cline { 3 - 7 } Examined & Examined & No. & $\%$ & Min & Max & Average \\
\hline Mehallabeia & 15 & 15 & 100 & $1 \times 10^{2}$ & $2.8 \times 10^{5}$ & $2.1 \times 10^{4}$ \\
\hline Rice with milk & 25 & 25 & 100 & $1 \times 10^{2}$ & $1.9 \times 10^{4}$ & $3.1 \times 10^{3}$ \\
\hline Ice cream & 30 & 30 & 100 & $4.3 \times 10^{2}$ & $8 \times 10^{4}$ & $2.4 \times 10^{4}$ \\
\hline Total & 70 & 70 & 100 & $1 \times 10^{2}$ & $8 \times 10^{4}$ & $1.6 \times 10^{4}$ \\
\hline
\end{tabular}

Table 2. Incidence and frequency distribution of dairy desserts samples based on their aerobic plate count.

\begin{tabular}{|c|c|c|c|c|c|c|}
\hline \multirow{2}{*}{$\begin{array}{c}\text { Counts/g } \\
\text { Or mil }\end{array}$} & \multicolumn{2}{|c|}{ Mehallabeia } & \multicolumn{2}{|c|}{ Rice with milk } & \multicolumn{2}{c|}{ Ice cream } \\
\hline $10-15$ & No.15 & No./25 & $\%$ & No./30 & $\%$ \\
\hline $10-10^{2}$ & - & 0.0 & - & 0.0 & - & 0.0 \\
\hline $10^{2}-10^{3}$ & 8 & 53.30 & 12 & 48 & 2 & 6.7 \\
\hline $10^{3}-10^{6}$ & 6 & 40 & 10 & 40 & 6 & 20 \\
\hline $10^{4}-10^{5}$ & - & 0.0 & 3 & 22 & 22 & 73.3 \\
\hline$>10^{5}$ & 1 & 6.7 & - & 0.0 & - & 0.0 \\
\hline Total & 15 & 100 & 25 & 100 & 30 & 100 \\
\hline
\end{tabular}

Table 3. Incidence and frequency distribution of dairy desserts samples based on their coliforms count.

\begin{tabular}{|c|c|c|c|c|c|c|}
\hline \multirow{2}{*}{$\begin{array}{c}\text { Counts/g } \\
\text { Or ml }\end{array}$} & \multicolumn{2}{|c|}{ Mehallabeia } & \multicolumn{2}{c|}{ Rice with milk } & \multicolumn{2}{c|}{ Icc cream } \\
\hline No/ 15 & $\%$ & No. $/ 25$ & $\%$ & No/30 & $\%$ \\
\hline $3-10$ & 3 & 20 & 4 & 16 & 2 & 6.6 \\
\hline $10-10^{2}$ & 1 & 6.7 & 2 & 8 & 8 & 26.7 \\
\hline $10^{2}-10^{7}$ & - & 0.0 & 1 & 4 & 6 & 20 \\
\hline $10^{3}-10^{4}$ & 2 & 13.3 & 2 & 8 & 14 & 46.7 \\
\hline $210^{4}$ & - & 0.0 & - & 0.0 & - & 0.0 \\
\hline Total & 6 & 40.0 & 9 & 36 & 30 & 100 \\
\hline
\end{tabular}

Table 4. Incidence and frequency distribution of dairy desserts samples based on their fecal coliforms count.

\begin{tabular}{|c|c|c|c|c|c|c|}
\hline \multirow{2}{*}{$\begin{array}{c}\text { Counts/g } \\
\text { Or ml }\end{array}$} & \multicolumn{2}{|c|}{ Mehallabeia } & \multicolumn{2}{c|}{ Rice with milk } & \multicolumn{2}{c|}{ lcc cream } \\
\cline { 2 - 7 } & No. $/ 15$ & $\%$ & No./25 & $\%$ & No. $/ 30$ & $\%$ \\
\hline $3-10$ & 4 & 26.7 & 3 & 12 & 10 & 33.3 \\
\hline $10-10^{2}$ & - & 0.0 & 4 & 16 & 6 & 20 \\
\hline $10^{2}-10^{3}$ & - & 0.0 & - & 0.0 & 1 & 3.3 \\
\hline $10^{2}-10^{4}$ & - & 0.0 & - & 0.0 & 3 & 10 \\
\hline$>10^{4}$ & - & 0.0 & - & 0.0 & - & 0.0 \\
\hline Total & 4 & 26.7 & 7 & 28 & 20 & 66.7 \\
\hline
\end{tabular}


Table 5. Incidence and frequency distribution of dairy desserts

\begin{tabular}{|c|c|c|c|c|c|c|}
\hline \multirow{2}{*}{$\begin{array}{c}\text { Counts/g } \\
\text { Or ml }\end{array}$} & Mehallabcia & \multicolumn{2}{|c|}{ Rice with milk } & \multicolumn{2}{c|}{ Ice cream } \\
\cline { 2 - 7 } & No./15 & $\%$ & No./25 & $\%$ & No./30 & $\%$ \\
\hline $3-10$ & 3 & 20 & 2 & 8 & 5 & 16.7 \\
\hline $10-10^{2}$ & - & 0.0 & 4 & 16 & 3 & 10 \\
\hline $10^{2}-10^{3}$ & - & 0.0 & - & 0.0 & 1 & 3.3 \\
\hline $10^{3}-10^{4}$ & - & 0.0 & - & 0.0 & 3 & 10 \\
\hline$>10^{6}$ & - & 0.0 & - & 0.0 & - & 0.0 \\
\hline Total & 3 & 20 & 6 & 24 & 12 & 40 \\
\hline
\end{tabular}

Table 6. Statistical analytical results of Enterococci in the examined dairy desserts samples.

\begin{tabular}{|c|c|c|c|c|c|c|}
\hline Samples & \multirow{2}{*}{$\begin{array}{c}\text { No. of samples } \\
\text { Examined }\end{array}$} & examined & Positive samples & \multicolumn{3}{|c|}{ Count/g or ml } \\
\cline { 3 - 7 } & No. & $\%$ & Min & Max & Average \\
\hline Mehallabeia & 15 & 8 & 53.3 & $8<100$ & 100 & $<100$ \\
\hline Rice with milk & 25 & 12 & 48 & $8<100$ & 100 & 100 \\
\hline Ice cream & 30 & 26 & 86.6 & 10 & $6.4 \times 10^{4}$ & $8.1 \times 10^{3}$ \\
\hline Total & 70 & 46 & 65.7 & 10 & $6.4 \times 10^{4}$ & $5.3 \times 10^{3}$ \\
\hline
\end{tabular}

- No colonies could be detected on the plate, however the samples proved to be positive after enrichment process.

Table 7. Incidence and requency distribution of dairy desserts samples based on their Enterococci count.

\begin{tabular}{|c|c|c|c|c|c|c|}
\hline \multirow{2}{*}{$\begin{array}{c}\text { Counts/g } \\
\text { or } \mathrm{m} !\end{array}$} & \multicolumn{2}{|c|}{ Mehallabcia } & \multicolumn{2}{c|}{ Rice with milk } & \multicolumn{2}{c|}{ Ice cream } \\
\cline { 2 - 7 } & No//15 & $\%$ & No/25 & $\%$ & No/30 & $\%$ \\
\hline 100 & 8 & 53.3 & 12 & 48 & 3 & 10 \\
\hline $10^{2}-10^{3}$ & - & 0.0 & - & 0.0 & 4 & 13.3 \\
\hline $10^{3}-10^{4}$ & - & 0.0 & - & 0.0 & 18 & 60 \\
\hline$>10^{4}$ & - & 0.0 & - & 0.0 & 1 & 3.3 \\
\hline Totul & 8 & 53.3 & 12 & 48 & 26 & 86.6 \\
\hline
\end{tabular}


Table 8. Statistical analytical results of total yeast \& molds count of the examined dairy desserts

\begin{tabular}{|c|c|c|c|c|c|c|}
\hline Samples & No. of samples & \multicolumn{2}{|c|}{ Positive samples } & \multicolumn{3}{|c|}{ Count/g or ml } \\
\cline { 3 - 7 } Examined & Examined & No. & $\%$ & Min & Max & Average \\
\hline Mehallabeia & 15 & 12 & 80 & $1 \times 10^{2}$ & $9 \times 10^{2}$ & $2.6 \times 10^{2}$ \\
\hline Rice with milk & 25 & 24 & 96 & 10 & $7 \times 10^{3}$ & $5.3 \times 10^{2}$ \\
\hline Iee cream & 30 & 30 & 100 & $7 \times 10^{2}$ & $3.9 \times 10^{4}$ & $1.2 \times 10^{4}$ \\
\hline Total & 70 & 66 & 94.28 & 10 & $3.9 \times 10^{4}$ & $5.4 \times 10^{3}$ \\
\hline
\end{tabular}

Table 9. Incidence and frequency distribution of dairy desserts samples bascd on their total yeast and molds count.

\begin{tabular}{|c|c|c|c|c|c|c|}
\hline \multirow{2}{*}{$\begin{array}{c}\text { Counts/g } \\
\text { or } \mathrm{ml}\end{array}$} & \multicolumn{2}{|c|}{ Mehallabeia } & \multicolumn{2}{c|}{ Rice with milk } & \multicolumn{2}{c|}{ Ice cream } \\
\cline { 2 - 7 } & No./15 & $\%$ & No./25 & $\%$ & No./30 & $\%$ \\
\hline 100 & - & 0.0 & 6 & 24 & - & 0.0 \\
\hline $10^{2}-10^{3}$ & 12 & 80 & 16 & 64 & 3 & 10 \\
\hline $10^{3}-10^{4}$ & - & 0.0 & 2 & 8 & 10 & 33.3 \\
\hline $10^{4}-10^{5}$ & - & 0.0 & - & 0.0 & 17 & 56.7 \\
\hline $10^{5}$ & - & 0.0 & - & 0.0 & - & 0.0 \\
\hline Total & 12 & 80 & 24 & 96 & 30 & 100 \\
\hline
\end{tabular}

